\title{
A fuzzy multi-criteria decision-making method for selection of criteria for an e-learning platform
}

\author{
Meral Güldeş $^{1 *}$, Ömer Faruk Gürcan ${ }^{2}$, Uğur Atici ${ }^{3}$, Cenk Şahin ${ }^{4}$ \\ 1* Cumhuriyet University, Faculty of Engineering, Departmant of Industrial Engineering, Sivas, Turkey, (ORCID: 0000-0001-6310-2504), mguldes@cumhuriyet.edu.tr \\ ${ }^{2}$ Cumhuriyet University, Faculty of Engineering, Departmant of Industrial Engineering, Sivas, Turkey, (ORCID: 0000-0002-1256-2751), ofgurcan@cumhuriyet.edu.tr \\ ${ }^{3}$ Cumhuriyet Üniversitesi, Faculty of Engineering, Departmant of Industrial Engineering, Sivas, Türkiye, (ORCID: 0000-0002-4389-9744), uatici@cumhuriyet.edu.tr \\ ${ }^{4}$ Çukurova University, Faculty of Engineering, Departmant of Industrial Engineering, Adana, Turkey, (ORCID: 0000-0002-6076-7794), cenksahin@cu.edu.tr
}

(International Conference on Design, Research and Development (RDCONF) 2021 - 15-18 December 2021)

(DOI: $10.31590 /$ ejosat.1041281)

ATIF/REFERENCE: Güldeş, M., Gürcan, Ö. F., Atici, U. \& Şahin, C. (2021). A fuzzy multi-criteria decision-making method for selection of criteria for an e-learning platform. European Journal of Science and Technology, (32), 797-806.

\begin{abstract}
Thanks to developing technology, one of the most significant changes in people's daily life routines have emerged in the education system. Due to developed software and hardware, people have begun to access, process, and share information regardless of time and place. Therefore, the internet-based teaching process, used alone or integrated with traditional education techniques, has brought many advantages and has become indispensable. Especially towards the end of 2019, the COVID-19 epidemic, which emerged in Wuhan, China, and spread worldwide, has again revealed that these systems have great importance for the future world. During the epidemic, traditional face-to-face education has been disrupted in many parts of the world, increasing online education. This situation has allowed increasing the number of studies on these systems. In particular, studies on the practical design of these systems are essential for the stakeholders of education systems. In this study, some significant criteria and sub-criteria are chosen based on literature and evaluated by using the fuzzy analytic hierarchy process.
\end{abstract}

Keywords: FAHP, Optimization, E-Learning, MCDM.

\section{Bir e-öğrenme platformu kriter seçimi için bulanık çok kriterli karar verme yöntemi}

$\ddot{\mathbf{O} z}$

Gelişen teknoloji sayesinde insanların günlük hayat rutinlerinde meydana gelen en büyük değişimlerden biri de eğitim sürecinde ortaya çıkmıştır. Geliştirilen yazılımlar ve donanımlar nedeniyle insanlar zaman ve mekandan bağımsız olarak bilgiye ulaşmaya, bilgiyi işlemeye ve paylaşmaya başlamışlardır. Tek başına veya geleneksel eğitim tekniklerine entegre olarak kullanılan internet tabanlı öğretim süreci pek çok avantajı da beraberinde getirmiş ve vazgeçilmez bir duruma gelmiştir. Özellikle 2019 yılının sonlarına doğru Çin'in Wuhan kentinde ortaya çıkan ve tüm dünyaya yayılan COVID-19 salgını bu sistemlerin geleceğin dünyası için büyük önem taşıdığını bir kere daha ortaya koymuştur. Salgın süresince geleneksel yüz yüze eğitim dünyanın pek çok bölgesinde sekteye uğramıştır ve online eğitim kullanımı artış göstermiştir. Bu durum bu sistemlerin konu edildiği çalışmaların da artmasına firsat vermiştir. Özellikle bu sistemlerin etkili tasarımlarını konu alan çalışmalar eğitim sistemlerinin paydaşları için önem arzetmektedir. Bu çalışmada önemli kriter ve alt kriterler literatüre göre seçilmiş ve bulanık analitik hiyerarşi methodu kullanılarak değerlendirlimiştir.

Anahtar Kelimeler: FAHP, Optimizasyon, E-öğrenme, ÇKKV.

\footnotetext{
*Corresponding Author: mguldes@cumhuriyet.edu.tr
} 


\section{Introduction}

E-Learning is a modern methodology that aims to improve education by improving teaching and learning processes in digital environments. The most important feature of these systems is that they allow education regardless of time and place. The developing technology supports the improvement of new tools and methodologies used on these platforms. In this way, they have become an essential part of the education systems of developed and developing countries worldwide. The education sector includes many different stakeholders. Each stakeholder evaluates the sector from their perspective. E-learning has been an essential factor in increasing the performance of the education system and the satisfaction level of the education system participants by providing fast and easy access to information via the World Wide Web (www). One of the crucial aspects of this method is to present an effective interactive environment to participants. Successful implementation of an e-learning system depends on various criteria. Therefore, it is vital to determine and evaluate these criteria to develop a functional design of these systems (Naveed et al., 2020).

In literature, different approaches are deployed to evaluate critical success factors of e-learning systems. Lin et al. (2021) present a combined Fuzzy Analytic Hierarchy Process (FAHP) and Rule-Space Model methodologies to lead and evaluate students' learning status for online educational sites (C. T. Lin, Chang, \& Chen, 2021). Upadhyay et al. (2021) present an analysis of the ergonomics-related disorders that can be emerged during online education by deploying FAHP to appraise ergonomicsrelated disorders. The disorders are identified, and these disorders' weights are figured out using triangle-shaped fuzzy numbers in pairwise comparison. The disorders are classified into four categories. These categories are evaluated and compared using FAHP according to their priorities (Upadhyay, Juneja, Juneja, Dhiman, \& Kautish, 2021). Chandna et al. (2021) present a study comparing two open online courses: Coursera and edX. Noticeable aspects of these online education sites are determined and compared by using the FAHP method (Chandna, Saini, \& Kumar, 2021). Li and Li (2020) present an organized math model for assessing online training system alternatives by using FAHP (L. Li \& Li, 2020). Wang and Lin (2019) appraise e-learning systems according to importance by using an integrated model consisting of FAHP and Association Rule Mining methods. These methods are used to rank criteria for assessing e-learning systems (Wang \& Lin, 2019). Turker Altun et al. (2019) presented a study to help institutions select an appropriate Learning Management Systems (LMS). FAHP, Fuzzy TOPSIS, and integrated method were used for evaluating criteria and deciding alternatives (Turker Altun, Baynal, \& Turker, 2019). Yadegaridehkordi et al. (2018) present a new approach that incorporates FAHP and Structural Equation Modelling to appraise the relative weight and importance of the factors of cloud-based collaborative learning technology (Yadegaridehkordi, Nizam Bin Md Nasir, Fazmidar Binti Mohd Noor, Shuib, \& Badie, 2018). Naveed et al. (2018) study the influence of barriers affecting e-learning systems. These barriers are appraised and prioritized by using FAHP to deal with them (Naveed et al., 2018). Anggrainingsih et al. (2018) study the e-learning success factors. FAHP method is used to determine the rank of factors' priorities (Anggrainingsih, Umam, \& Setiadi, 2018). Pour et al. (2017) presents a framework for appraising elearning systems by deploying FAHP and balanced scorecard methods (Jami Pour, Hosseinzadeh, Bagherzadeh Azar, \& Taheri,
2017). Garg and Jain (2017) study the selection of E-learning websites by using the Fuzzy Multiple Attribute Decision-Making method. The selection index is constructed, and FAHP determines its weights. Then Complex Proportional Assessment (COPRAS), Multicriteria Optimization and Compromise Solution (VIseKriterijumska Optimizacija I Kompromisno ResenjeVIKOR), and Weighted Distance-based Approximation (WDBA) are used for ranking alternatives (Garg \& Jain, 2017). Başaran and Haruna (2017) propose a model for quality and user satisfaction and evaluate mobile learning applications, particularly for mathematics, by applying FAHP and Technique for Order of Preference by Similarity to Ideal Solution (TOPSIS) methods together (Başaran \& Haruna, 2017). Kurilovas and Vinogradova (2016) present a methodology to assess the quality of distance learning courses. The methodology contains a criteria system and a new quality evaluation method established on Fuzzy and AHP methods (Kurilovas \& Vinogradova, 2016). Nagpal et al. (2015) present a study to evaluate the usability of the website of an educational institute by using FAHP (Nagpal, Mehrotra, Bhatia, \& Bhatia, 2015). Mazaheri et al. (2015) present an assessment framework to evaluate the students' performance in e-learning systems. Six main criteria and 24 sub-criteria are determined and evaluated by using FAHP (Mazaheri Asad, Ebrahimi Kermani, \& Monteiro da Hora, 2015). Işık et al. (2015) use FAHP methodology to evaluate and select a suitable LMS (Işı, Ince, \& Yigit, 2015). Chang et al. (2015) use the Fuzzy Delphi method (FDM) and Fuzzy FAHP to determine the critical success factors of knowledge management for university students using eportfolio (Chang, Liang, Shu, \& Tsai, 2015). Wang and Lin (2012) use FAHP and Association Rule to assess the process of "Practice Score" and "Interactive Learning" (Wang \& Lin, 2012). Wan et al. (2012) use FAHP to evaluate the Learning Content Management System (LCMS) and select the best LCMS according to qualitative and quantitative criteria (Wan, Shi, \& Zhao, 2012). Li et al. (2012) present an assessment index system for evaluating internet learning quality (W. Li, Gao, \& Fu, 2012). Mehregan et al. (2011a) present a study to identify and prioritize e-learning critical success factors (CSFs) to help educational institutes and universities for developing e-learning system plans (Mehregan, Jamporazmey, Hosseinzadeh, \& Mehrafrouz, 2011a). Mehregan et al. (2011b) present an approach to identify and prioritize the critical success factors (CSFs) of e-learning systems by using FAHP (Mehregan, Jamporazmey, Hosseinzadeh, \& Mehrafrouz, 2011b). Lo et al. (2011) construct a hierarchical factor table by using FAHP for firms implementing customized elearning systems (Lo, Chang, Shieh, \& Chung, 2011). Yang and Chen (2010) analyze students' self-learning ability in a network environment using fuzzy mathematics. Then, AHP is used to build students' self-learning evaluation index system and evaluation model (Yang \& Chen, 2010). Xing (2010) used FAHP to establish a model for evaluating web-based courses (Xing, 2010). Tseng et al. (2010) present an approach to establish an adaptive curriculum portfolio recommendation system (Tseng, Chang, \& Chou, 2010). Lin (2010) presents an approach in which FAHP and fuzzy triangular numbers are integrated to identify the factors influencing the effectiveness of a course website (H. F. Lin, 2010). Jie (2010) presents a literature review to determine criteria and sub-criteria for online course quality assessment. A fuzzy evaluation model is deployed to prioritize the relative weights of online course quality factors (Jie, 2010). Hong (2010) present an assessment framework to determine the sustainability of virtual communities under e-learning platform in university, and FAHP is used for data pairwise comparison (Hong, 2010). Liu et al. 
(2009) use FAHP to assess the factors influencing an e-learning platform (Liu, Peng, Chen, \& Xie, 2009). Chen (2019) assesses elearning service companies by identifying and prioritizing their measures of intellectual capital (Chen, 2009). Chao and Chen (2009) assess a web e-learning system by using the consistent fuzzy preference relations (CFPR) in the AHP model by examining several criteria (Chao \& Chen, 2009). Bo et al. (2009) assess the capability of network education in China. The fuzzy synthetic judgment method and AHP are used to build an assessment system (Bo, Xuning, \& Bingquan, 2009).

This study uses the FAHP method to assess the criteria and sub-criteria to decide the most important ones for e-learning. Previous studies are examined and used criteria, and sub-criteria are determined by investigating extensive literature review studies (Naveed et al., 2020; Zare et al., 2016). Finally, seven criteria and thirty-one sub-criteria are chosen and evaluated by experts.

\section{Material and Method}

\subsection{Evaluation Criteria}

In this study, seven main criteria and thirty-one sub-criteria are selected based on the literature to evaluate the e-learning platform of Cumhuriyet University. All of the criteria are presented in Table 1.

Table 1. Main and sub-criteria.

\begin{tabular}{|c|c|}
\hline Main Criteria & Sub Criteria \\
\hline \multirow{4}{*}{ Framework $(\mathrm{C} 1)$} & C11 Navigation \\
\hline & C12 Offline access \\
\hline & C13 User-friendliness \\
\hline & C14 Report \\
\hline \multirow{6}{*}{ Function (C2) } & C21 User control \\
\hline & C22 History \\
\hline & C23 Search \\
\hline & C24 Lecture duration control \\
\hline & C25 Customization \\
\hline & "C26 Whiteboard sharing \\
\hline \multirow{4}{*}{ Security (C3) } & C31Authorization \\
\hline & C32 Password security \\
\hline & C33 Virus protection \\
\hline & C34 Authentication \\
\hline \multirow{4}{*}{ Material (C4) } & C41 Sufficient education material \\
\hline & C42 Pedagogical material \\
\hline & C43 Additional material \\
\hline & C44 Document library \\
\hline \multirow{5}{*}{$\begin{array}{c}\text { Collaboration } \\
\text { (C5) }\end{array}$} & C51 Data sharing \\
\hline & C52 Mail-message \\
\hline & C53 Content sharing \\
\hline & C54 Questioner \\
\hline & C55 Interactive mode \\
\hline \multirow{4}{*}{ Quality (C6) } & "C61 System user satisfaction \\
\hline & C62 Internet connection quality \\
\hline & C63 Audit \\
\hline & C64 Up-to-date content \\
\hline \multirow{4}{*}{ Assessment (C7) } & C71 Exercises-Quizzes Exams \\
\hline & C72 Attendance \\
\hline & C73 Progress tracking \\
\hline & C74 Projects \\
\hline
\end{tabular}

The criteria, namely, Framework (C1), contains four subcriteria. The sub-criteria of Framework $(\mathrm{C} 1)$ are Navigation (C11), Offline Access (C12), User-Friendliness (C13), and Report (C14).

- Navigation is related to the clearness and easiness of navigation in the platform's menus, interfaces, or subpage hierarchy.

- Offline access is related to accessing videos or documents of lessons offline.

- User-friendliness meaning is that the portal is easy to understand and use; has desirable interfaces which increase user satisfaction.

- The report is the ability of portal framework design to give customized or standard reports to users.

The criteria, namely, Function (C2), contains six sub-criteria. These are user control (21), history (22), search (23), lesson duration control (24), customization (25), and whiteboard sharing (26).

- User control is related to the ability of both academicians and students to organize learning activities.

- History gives the records of the learning process such as lesson durations, video uploading times, internet connection history, user activity information, etc.

- Search is the effectiveness of this function to access intended information in the platform.

- Lesson duration control is the easiness of controlling the duration of an online lesson and video records by academicians.

- Customization is related to the customization degree of a platform according to user desires/needs.

- Whiteboard sharing is a platform's capability to enable academicians to share whiteboards during online lessons.

The criteria, namely, Security (C3), has four sub-criteria. These are authorization (C31), password reset (C32), virus protection (C33), authentication (C34).

- Authorization is related to the degree of permissions given to users during the platform's usage.

- Password security is the easiness and security of getting new robust passwords by users and restoring the account.

- Virus protection is the effectiveness of anti-virus protection of the platform.

- Authentication is related to verifying the identity of users and processes.

The criteria, namely, Material (C4), has four sub-criteria. These are sufficient education material (C41), pedagogical material (C42), additional material (C43), and document library (C44).

- Sufficient Education material is related to the richness of materials used in lessons.

- Pedagogical material related to pedagogic consideration in used/shared materials.

- Additional material is related to the richness of additional materials are offered by academicians in the training process.

- Document library enables users to manage, update, distribute and use educational documents. 
The criteria, namely, Collaboration (C5), has five subcriteria. These are data sharing (51), mail/message (52), content sharing (53), questionnaire (54), and interactive mode (55).

- Data sharing lets users share related data during online lessons or offline.

- Mail/message lets users communicate during online lessons or offline.

- Content sharing is related to communicating using other platforms such as social media, Document Library, Google Drive, WeTransfer, One Drive.

- The questionnaire enables the academicians to share various questionnaires with students.

- Interactive mode is presented that the portal has interactive learning processes.

The criteria, namely, Quality (C6), has four sub-criteria. These are system user satisfaction (61), connection quality (62), content audit (63), and up-to-date content (64).

- User satisfaction gives overall satisfaction pf users from the platform.

- Connection quality shows the internet connection capability in terms of speed, stability, quota, disconnection, etc.

- The audit is a control mechanism that is a process of systematically reviewing all the content in the platform and evaluating students

- Up-to-date content provides all of the content to be up to date, which increases user satisfaction.

The last criteria, namely, Assessment (C7), has four subcriteria. These are exercises/quizzes/exams (71), attendance (72), progress tracking (73), and projects (74).

- Academicians do exercises/quizzes/exams to assess the success of students.

- Attendance is checked to meet course pass requirements.

- Progress tracking enables academicians to track students' overall success in projects, exams, and other activities.

- Projects are additional assessment criteria in training.

\subsection{Fuzzy AHP}

In decision-making problems, linguistic expressions are subjective, and vagueness and uncertainty of decision settings can reason problems during the evaluation of decision-makers. The fuzzy sets can be used to handle such problems in modeling so that more exact results can be achieved. Fuzzy sets were proposed by Zadeh (1965). A membership function characterizes each element in a fuzzy set by assigning the elements to set with membership degrees in the range of $[0,1]$. There are various types of fuzzy sets in the literature such as type-1, type-2 fuzzy sets, intuitionistic fuzzy sets, hesitant fuzzy sets, etc. (Güldeş, Atici, \& Şahin, 2021; Gürcan, Yazıcı, Beyca, Arslan, \& Eldemir, 2016; Yazici et al., 2020).

The Multi-Criteria Decision Making (MCDM) techniques are widely applied in decision-making problems (Akcan \& Güldeş, 2019). These techniques give mathematical methodology that involves values of stakeholders and decision-makers besides technical information to choose the best solution for different problems. MCDM enables more logical and scientifically defendable decisions to be made. A typical MCDM application has the following processes: The problem is defined where overall structure and decision-makers are described. The problem is structured by defining related alternatives and criteria. The criteria are used in deciding on alternatives. Then, criteria and alternatives are assigned numeric values. Criteria are weighted by decisionmakers. The alternatives get scored overlooking criteria. Model is applied using criteria weights and scoring of alternatives (Linkov \& Moberg, 2011).

There are many MCDM techniques. The best alternative is determined with quantitative and qualitative criteria and frequently with conflicting criteria. One of the widely used techniques is Analytical Hierarchy Process (AHP), which was developed by Saaty (Saaty, 1977, 1980). AHP is an incredibly beneficial method when the decision-maker is inadequate to build a utility function. There are four steps in obtaining a rank for alternatives in the AHP application. Firstly, the problem should be structured like a typical property of MCDM methods. The problem is structured using a hierarchy including some levels such that level of goal of problem, criteria, sub-criteria, and alternatives. Then priorities (priorities of criteria, local alternative, and global alternative) or scores are calculated depending on pairwise comparisons ensured by the user. A numerical judgment is not obligatory for decision-makers. A relative verbal evaluation is sufficient. Later, a consistency check and a sensitivity analysis are made, optional but advised to obtain robust results. A consistency check helps to reveal possible contradictions in input data. On the other hand, sensitivity analysis lets different scenarios be produced, where input data is changed slightly to monitor the impact on results. As a result, different scenarios can give the same alternatives (robust results), or ranking can be changed (sensitive results) (Ishizaka \& Nemery, 2013).

In this study, we decided to use Type-1 fuzzy sets with the AHP technique. The linguistic variables and related fuzzy scales used in the current study are given in Table 2.

Table 2. Linguistic variables and fuzzy triangular numbers.

\begin{tabular}{|l|c||}
\hline \multicolumn{1}{|c||}{ Linguistic Variables } & Fuzzy scale \\
\hline \hline Equally Important & $(1,1,1)$ \\
\hline Moderately Important & $(2,3,4)$ \\
\hline Strongly Important & $(4,5,6)$ \\
\hline Very Strongly Important & $(6,7,8)$ \\
\hline \hline Absolutely Important & $(9,9,9)$ \\
\hline
\end{tabular}

Pairwise comparisons matrices are produced, given in Equation (1), considering pairwise comparisons between the criteria. The corresponding linguistic expressions are determined to compare the importance of the criteria. The fuzzy geometric mean is found applying Equation (2).

$$
\begin{aligned}
\widetilde{M} & =\left[\begin{array}{ccccc}
1 & \tilde{m}_{12} & \tilde{m}_{13} & \ldots & \tilde{m}_{1 n} \\
\widetilde{m}_{21} & \tilde{m}_{22} & \tilde{m}_{23} & \ldots & \widetilde{m}_{2 n} \\
\vdots & \vdots & \vdots & \ddots & \vdots \\
\tilde{m}_{n 1} & \tilde{m}_{n 2} & \tilde{m}_{n 3} & \ldots & 1
\end{array}\right] \\
\tilde{g}_{\mathrm{i}} & =\left(\tilde{m}_{i 1} \otimes \widetilde{m}_{i 2} \otimes \ldots \otimes \tilde{m}_{i n}\right)^{1 / n}
\end{aligned}
$$

The fuzzy weight of each criterion is found using Equation (3). The vector sum of each $\tilde{g}_{i}$ is attained.

$$
\widetilde{w}_{\mathrm{i}}=\tilde{g}_{i \otimes}\left(\tilde{g}_{1} \otimes \tilde{g}_{2} \otimes \ldots \otimes \tilde{g}_{n}\right)^{-1}
$$


The performance value of each criterion is calculated using Equation (4), where $\mathrm{P}$ is a non-fuzzy value. In this equation, (u, $\mathrm{m}, \mathrm{l}$ ) is a triangular fuzzy number where $\mathrm{u}, \mathrm{m}, \mathrm{l}$ present the the highest, mid, the lowest possible value of an fuzzy event, respectively. Then, it is normalized using Equation (5).

$$
\begin{aligned}
& P_{i}=\frac{l w_{i}+m w_{i}+u w_{i}}{3} \\
& w_{i}=\frac{P_{i}}{\sum_{j=1}^{n} P_{i}}
\end{aligned}
$$

A fuzzy set, $\tilde{F}$ is defined in $[0,1]$ presented in Equation (6).

$\mu_{\tilde{F}}: E \rightarrow[0,1]$

$\mu_{F(x)}\left\{\begin{array}{cc}0, & x \leq a \\ \frac{x-a}{b-a} & a \leq x \leq b \\ \frac{c-x}{c-b} & b \leq x \leq c \\ 0, & x \geq c\end{array}\right.$

The steps of the FAHP process are summarized in Figure 1.

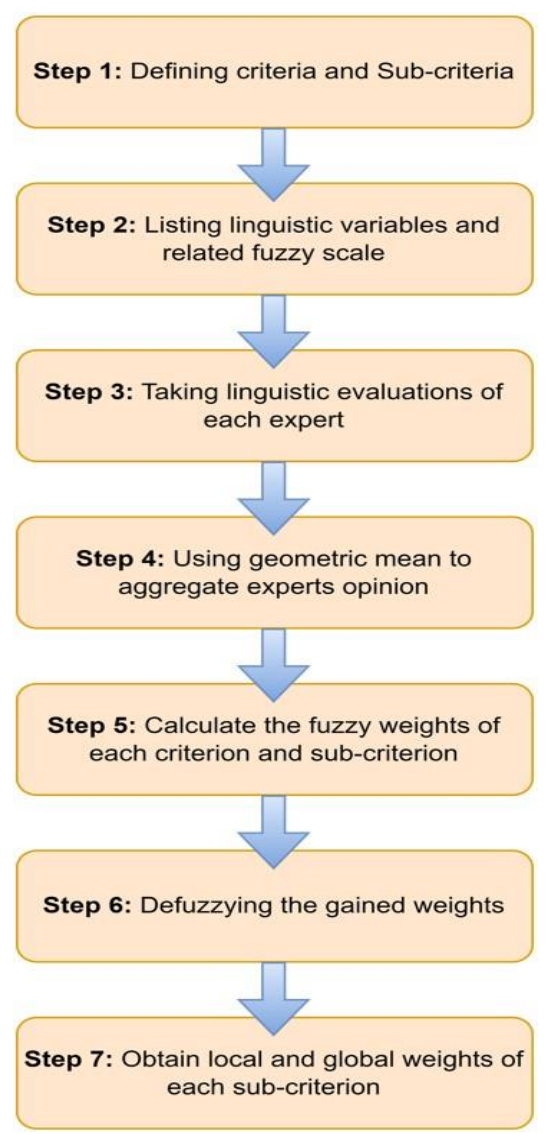

Figure 1. Steps of FAHP process.

\section{3. e-Learning System of Cumhuriyet University}

Due to the Covid 19 epidemic, distance education was provided at Sivas Cumhuriyet University in the spring term of 2020-2021. Hybrid education is offered in the recent spring semester: face-to-face and online.

In the spring semester, Atatürk's Principles and Revolution History, Turkish Language and Foreign Language courses within the scope of the $5 \mathrm{i}$, which are compulsory in all programs, and İLITAM program courses are conducted online.
Distance education consists of three platforms: Student Information System (SIS), Learning Management System (LMS), and Microsoft Teams. These platforms can work over the web, and users $\log$ in under authentication and authorization procedures. Institutional e-mail addresses, passwords, student or academic staff registration numbers, and ID numbers are needed. The integrated e-learning system of Cumhuriyet University is presented in Figure 2.

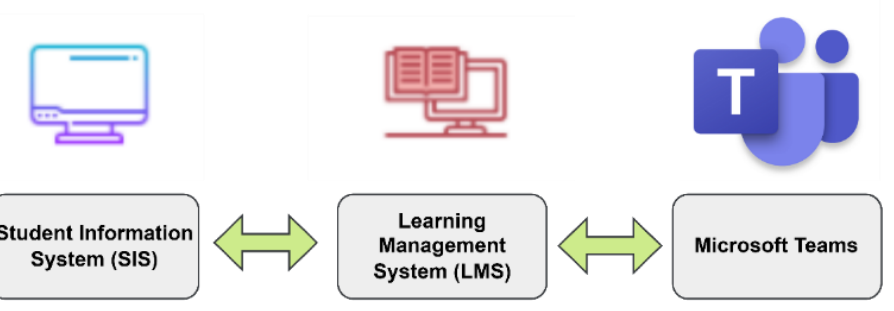

Figure 2. The integrated e-learning system of the university.

Microsoft Teams: Online lessons are held over the Microsoft Teams system. Therefore, this program must be installed on a user's computer or mobile phone. Online lessons are held during the lesson hours specified in the lesson program and defined in the Microsoft Teams system. A make-up program is made for the lessons that cannot be completed on time or delayed. Students sign up for live classes (aka classes or teams) using Microsoft Teams. The team code required to become a member announces on the LMS or SIS. Online lessons cannot be watched without the team code. With Microsoft Teams working on the web, installing Teams on computers, tablets, and mobile phones allows the online lesson to run more smoothly. Watching the videos in the archive is also done through Microsoft Teams.

Learning Management System (LMS): The courses to be taken by the students are uploaded to the LMS. The links of the courses with video footage are added in LMS in the relevant weeks. In addition, to live lessons, pdf, ppt, lecture notes, etc., course materials are uploaded to LMS. The authorities do the tracking of whether the course materials are uploaded in the relevant week via LMS. Giving homework, projects, and applications to students and uploading them to the system by students is done via LMS. LMS is used to take online exams. Academic advisors are responsible for solving possible problems that students with disabilities may encounter in distance education. Messages sent by students via LMS are frequently checked and answered by academicians as soon as possible. Additionally, students can access exam information and various announcements via this platform. The LMS interface is given in Figure 3.

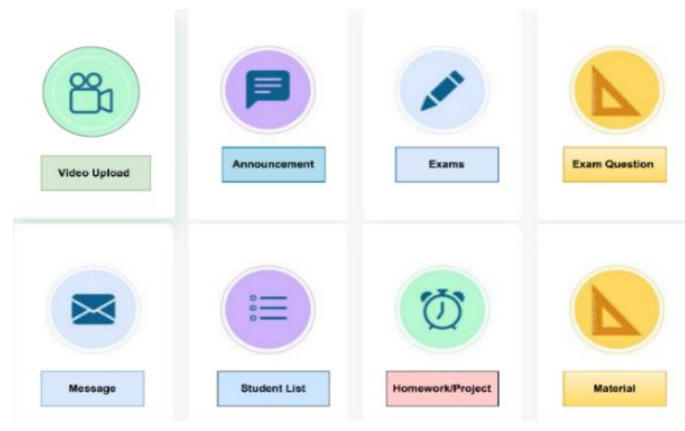

Figure 3. LMS interface. 
Student Information System (SIS) is an academic information system. This system gives information on course processes (such as academic calendar, syllabus), student advising process (such as course registration, listing students being advisor, graduation

\section{Result and Discussion}

Seven main criteria and thirty-one sub-criteria have been determined for the evaluation of our university's e-learning system. Which features should be given more importance in the development of the current learning system was determined by using the FAHP method. Evaluations were made by a team of experts (ET) working in administrative and academic positions. A summary linguistic evaluations of criteria is presented in Table 3.

Geometric means were calculated using Equation (2). After calculating the geometric mean of the main criteria, the fuzzy weights of the sub-criteria are calculated. The geometric mean of fuzzy comparison value for each sub-criterion is presented in Table 4.

The relative fuzzy weight of each criterion is calculated by using Equation (3). The relative fuzzy weight of each criterion is shown in Table 5. permission), exam process (such as exam calendar, exam results, exam registration), some user processes (such as academic $\mathrm{CV}$, HES code, announcements, messages, user profile information).

The calculated weights are defuzzified and normalized. The criteria weights normalized by averaging are presented in Table 6. The calculated ranked weights of main and sub-criteria are presented in Table 7 and Table 8, respectively.

Table 3. The linguistic evaluations of criteria.

\begin{tabular}{|c||c||c||c||c|c||}
\hline & $\mathrm{C} 1$ & $\mathrm{C} 2$ & $\mathrm{C} 3$ & $\cdots$ & $\mathrm{C} 31$ \\
\hline \hline $\mathrm{C} 1$ & $\mathrm{EE}$ & $\mathrm{C} 1 \& \mathrm{C} 2$ & $\mathrm{C} 1 \& \mathrm{C} 3$ & $\cdots$ & $\mathrm{C} 1 \& \mathrm{C} 31$ \\
\hline $\mathrm{C} 2$ & $1 / \mathrm{C} 1 \& \mathrm{C} 2$ & $\mathrm{EE}$ & $\mathrm{C} 2 \& \mathrm{C} 3$ & $\cdots$ & $\mathrm{C} 2 \& \mathrm{C} 31$ \\
\hline \hline $\mathrm{C} 3$ & $1 / \mathrm{C} 1 \& \mathrm{C} 3$ & $1 / \mathrm{C} 2 \& \mathrm{C} 3$ & $\mathrm{EE}$ & $\cdots$ & $\mathrm{C} 3 \& \mathrm{C} 31$ \\
\hline \hline$\vdots$ & $\vdots$ & $\vdots$ & $\vdots$ & $\vdots$ & $\vdots$ \\
\hline $\mathrm{C} 31$ & $1 / \mathrm{C} 1 \& \mathrm{C} 31$ & $1 / \mathrm{C} 2 \& \mathrm{C} 31$ & $1 / \mathrm{C} 3 \& \mathrm{C} 31$ & $\cdots$ & $\mathrm{EE}$ \\
\hline
\end{tabular}

Table 4. The geometric mean of fuzzy comparison.

\begin{tabular}{|l||c|c|c|}
\hline \multicolumn{1}{|c||}{ Criteria } & \multicolumn{3}{c|}{$\boldsymbol{r}_{\boldsymbol{i}}$} \\
\hline C11 Navigation & 0.277 & 0.303 & 0.255 \\
\hline C12 Offline access & 4.315 & 4.415 & 3.745 \\
\hline C13 User friendly & 0.450 & 0.443 & 0.434 \\
\hline C14 Report & 0.319 & 0.396 & 0.401 \\
\hline C21 User control & 0.365 & 0.357 & 0.417 \\
\hline C22 History & 0.356 & 0.321 & 0.346 \\
\hline C23 Search & 0.411 & 0.405 & 0.438 \\
\hline C24 Lecture duration control & 0.371 & 0.405 & 0.451 \\
\hline C25 Customization & 0.418 & 0.376 & 0.429 \\
\hline C26 Whiteboard sharing & 1.720 & 1.606 & 1.620 \\
\hline C31 Authorization & 1.445 & 1.560 & 1.491 \\
\hline C32 Password security & 2.564 & 3.076 & 2.643 \\
\hline \hline C33 Virus protection & 2.568 & 2.854 & 2.607 \\
\hline C34 Authentication & 2.055 & 1.694 & 1.966 \\
\hline C41 Sufficient education material & 2.600 & 2.819 & 2.751 \\
\hline C42 Pedological material & 2.207 & 2.378 & 2.244 \\
\hline C43 Additional material & 1.168 & 1.166 & 1.172 \\
\hline C44 Document library & 0.735 & 0.730 & 0.743 \\
\hline C51 Data sharing & 0.651 & 0.580 & 0.621 \\
\hline C52 Mail-message & 0.609 & 0.591 & 0.611 \\
\hline C53 Content sharing & 0.891 & 0.857 & 0.907 \\
\hline C54 Questionary & 0.979 & 0.992 & 0.966 \\
\hline C55 Interactive mode & 1.300 & 1.407 & 1.323 \\
\hline C61 System user satisfaction & 0.640 & 0.659 & 0.655 \\
\hline C62 Internet connection quality & 2.852 & 2.902 & 2.917 \\
\hline C63 Content audit & 1.994 & 1.983 & 1.970 \\
\hline C64 Up-to-date content & 1.851 & 2.008 & 2.053 \\
\hline C71 Exercises-Quizes Exams & 3.493 & 3.397 & 3.734 \\
\hline C72 Attendance & 0.895 & 0.887 & 0.910 \\
\hline C73 Progress tracking & 1.054 & 1.075 & 1.094 \\
\hline C74 Projects & 0.290 & 0.297 & 0.326 \\
\hline & & & \\
\hline
\end{tabular}


Table 5. Relative fuzzy weight of criteria.

\begin{tabular}{|l||c||c|c|}
\hline \multicolumn{1}{|c|}{ Criteria } & \multicolumn{3}{c|}{$\boldsymbol{w}_{\boldsymbol{i}}$} \\
\hline \hline C11 Navigation & 0.006 & 0.007 & 0.006 \\
\hline \hline C12 Offline access & 0.100 & 0.105 & 0.090 \\
\hline C13 User friendly & 0.010 & 0.010 & 0.010 \\
\hline \hline C14 Report & 0.007 & 0.009 & 0.010 \\
\hline \hline C21 User control & 0.008 & 0.008 & 0.010 \\
\hline \hline C22 History & 0.008 & 0.008 & 0.008 \\
\hline \hline C23 Search & 0.010 & 0.010 & 0.010 \\
\hline C24 Lecture duration control & 0.009 & 0.010 & 0.011 \\
\hline C25 Customization & 0.010 & 0.009 & 0.010 \\
\hline \hline C26 Whiteboard sharing & 0.040 & 0.038 & 0.039 \\
\hline \hline C31 Authorization & 0.034 & 0.037 & 0.036 \\
\hline \hline C32 Password security & 0.060 & 0.073 & 0.063 \\
\hline C33 Virus protection & 0.060 & 0.068 & 0.062 \\
\hline \hline C34 Authentication & 0.048 & 0.040 & 0.047 \\
\hline C41 Sufficient education material & 0.061 & 0.067 & 0.066 \\
\hline \hline C42 Pedological material & 0.051 & 0.056 & 0.054 \\
\hline \hline C43 Additional material & 0.027 & 0.028 & 0.028 \\
\hline \hline C44 Document library & 0.017 & 0.017 & 0.018 \\
\hline C51 Data sharing & 0.015 & 0.014 & 0.015 \\
\hline \hline C52 Mail-message & 0.014 & 0.014 & 0.015 \\
\hline C53 Content sharing & 0.021 & 0.020 & 0.022 \\
\hline \hline C54 Questionary & 0.023 & 0.023 & 0.023 \\
\hline \hline C55 Interactive mode & 0.030 & 0.033 & 0.032 \\
\hline C61 System user satisfaction & 0.015 & 0.016 & 0.016 \\
\hline C62 Internet connection quality & 0.066 & 0.069 & 0.070 \\
\hline \hline C63 Content audit & 0.046 & 0.047 & 0.047 \\
\hline \hline C64 Up-to-date content & 0.043 & 0.048 & 0.049 \\
\hline \hline C71 Exercises-quizes-exams & 0.081 & 0.080 & 0.089 \\
\hline \hline C72 Attendance & 0.021 & 0.021 & 0.022 \\
\hline C73 Progress tracking & 0.025 & 0.025 & 0.026 \\
\hline C74 Projects & 0.007 & 0.007 & 0.008 \\
\hline & & & \\
\hline
\end{tabular}

Tablo 6. Average and normalized weight of criteria.

\begin{tabular}{|l|c|c|}
\hline \multicolumn{1}{|c|}{ Sub- criteria } & $\boldsymbol{\mu}_{\boldsymbol{i}}$ & $\boldsymbol{n}_{\boldsymbol{i}}$ \\
\hline C11 Navigation & 0.007 & 0.00657 \\
\hline \hline C12 Offline access & 0.098 & 0.09815 \\
\hline C13 User friendly & 0.010 & 0.01045 \\
\hline C14 Report & 0.009 & 0.00879 \\
\hline \hline C21 User control & 0.009 & 0.00897 \\
\hline C22 History & 0.008 & 0.00805 \\
\hline \hline C23 Search & 0.010 & 0.00987 \\
\hline C24 Lecture duration control & 0.010 & 0.00966 \\
\hline C25 Customization & 0.010 & 0.00963 \\
\hline \hline C26 Whiteboard sharing & 0.039 & 0.03892 \\
\hline C31 Authorization & 0.035 & 0.03540 \\
\hline \hline C32 Password security & 0.065 & 0.06523 \\
\hline C33 Virus protection & 0.063 & 0.06322 \\
\hline C34 Authentication & 0.045 & 0.04498 \\
\hline \hline C41 Sufficient education material & 0.064 & 0.06433 \\
\hline \hline
\end{tabular}




\begin{tabular}{|l|c|c|}
\hline C42 Pedological material & 0.054 & 0.05377 \\
\hline \hline C43 Additional material & 0.028 & 0.02760 \\
\hline C44 Document library & 0.017 & 0.01738 \\
\hline \hline C51 Data sharing & 0.015 & 0.01458 \\
\hline C52 Mail-message & 0.014 & 0.01426 \\
\hline \hline C53 Content sharing & 0.021 & 0.02090 \\
\hline C54 Questionary & 0.023 & 0.02311 \\
\hline C55 Interactive mode & 0.032 & 0.03173 \\
\hline \hline C61 System user satisfaction & 0.015 & 0.01539 \\
\hline C62 Internet connection quality & 0.068 & 0.06827 \\
\hline C63 Content audit & 0.047 & 0.04682 \\
\hline \hline C64 Up-to-date content & 0.047 & 0.04657 \\
\hline \hline C71 Exercises-Quizes Exams & 0.084 & 0.08366 \\
\hline \hline C72 Attendance & 0.021 & 0.02120 \\
\hline \hline C73 Progress tracking & 0.025 & 0.02537 \\
\hline \hline C74 Projects & 0.007 & 0.00718 \\
\hline
\end{tabular}

Table 7. Ranked global weights main criteria.

\begin{tabular}{|l|c|}
\hline \multicolumn{1}{|c||}{ Main criteria } & $\mathbf{n}_{\mathbf{i}}$ \\
\hline \hline Security (C3) & 0.208864671 \\
\hline \hline Quality (C6) & 0.177068088 \\
\hline Material (C4) & 0.163103562 \\
\hline \hline Assessment (C7) & 0.13743323 \\
\hline \hline Framework (C1) & 0.123984207 \\
\hline \hline Collaboration (C5) & 0.104599908 \\
\hline \hline Function (C2) & 0.085117475 \\
\hline
\end{tabular}

Table 8. Ranked weights sub-criteria.

\begin{tabular}{|l|c|}
\hline \multicolumn{1}{|c|}{ Sub- criteria } & $\mathbf{n}_{\mathbf{i}}$ \\
\hline C12 Offline access & 0.098153 \\
\hline C71 Exercises-Quizes Exams & 0.083656 \\
\hline C62 Internet connection quality & 0.068271 \\
\hline \hline C32 Password security & 0.065228 \\
\hline C41 Sufficient education material & 0.06433 \\
\hline C33 Virus protection & 0.063221 \\
\hline \hline C42 Pedological material & 0.053767 \\
\hline \hline C63 Audit & 0.046815 \\
\hline C64 Up-to-date content & 0.046565 \\
\hline C34 Authentication & 0.044975 \\
\hline \hline C26 Whiteboard sharing & 0.038922 \\
\hline C31 Authorization & 0.035404 \\
\hline C55 Interactive mode & 0.03173 \\
\hline \hline C43 Additional material & 0.027601 \\
\hline \hline C73 Progress tracking & 0.025372 \\
\hline
\end{tabular}

\section{Conclusions and Recommendations}

Due to the COVID-19 pandemic, the use of distance education systems has become widespread. Many different institutions, from health to universities, continued their education activities through distance education systems. Therefore, it should be determined which criteria will be used to develop LMS systems and which features of LMS systems are essential for academics, students, and users.

In this study, the criteria to develop the LMS system selected for the application study were determined. FAHP multi-criteria decision-making method was used.

e-ISSN : 2148-2683
In this study, the criteria and sub-criteria were selected by a comprehensive literature review. The fuzzy analytical hierarchy method was used to prioritize the e-learning platforms criteria. Seven criteria and 31 sub-criteria were determined to evaluate elearning platforms. According to the weight values, the first three main criteria were Security (C3), Quality (C6), and Material (C4). Security (C3), which means the security of information such as account, evaluation system, and exam results, has been the most critical criterion. It has been determined that account reliability concerns over the entire system take precedence over other criteria. Here, ET has prioritized its concerns regarding the storage of exam questions and results. ET gives second 
importance to Quality (C6). The second priority was given to the reliability of the internet connection and the supervision of the evaluation mechanism of the students, which are necessary conditions for distance education. ET is the third most crucial criterion, Material (C4).

According to the global weight values first ten sub-criteria are with C12 Offline access, C71 Exercises-Quizzes Exams, C62 Internet connection quality, C32 Password security, C41 Sufficient education material, C33 Virus protection, C42 Pedological material, C63 Audit, C64 Up-to-date content.

This study presents a reasonable criterion for determining the features to be prioritized in the development of LMS systems. Furthermore, the method proposed in this study can be used to determine which features will be improved in updating other elearning systems.

\section{References}

Akcan, S., \& Güldeş, M. (2019). Integrated multi-criteria decision-making methods to solve supplier selection problem: a case study in a hospital. Journal of healthcare engineering, 2019.

Anggrainingsih, R., Umam, M., \& Setiadi, H. (2018). Determining e-learning success factor in higher education based on user perspective using Fuzzy AHP. MATEC Web of Conferences, 154, 03011. doi: 10.1051/ matecconf/ 201815403011

Başaran, S., \& Haruna, Y. (2017). Integrating FAHP and TOPSIS to evaluate mobile learning applications for mathematics.

Bo, L., Xuning, P., \& Bingquan, B. (2009). Modeling of network education effectiveness evaluation in fuzzy analytic hierarchy process. Paper presented at the 2009 International Conference on Networking and Digital Society.

Chandna, R., Saini, S., \& Kumar, S. (2021). Fuzzy AHP based performance evaluation of massive online courses provider for online learners.

Chang, C. C., Liang, C., Shu, K. M., \& Tsai, C. W. (2015). Key successful factors of knowledge management for university students using e-portfolios: Approach of Fuzzy Delphi and Fuzzy AHP. Computer Applications in Engineering Education, 23(5), 673-681.

Chao, R. J., \& Chen, Y. H. (2009). Evaluation of the criteria and effectiveness of distance e-learning with consistent fuzzy preference relations. Expert Systems with Applications, 36(7), 10657-10662. doi:10.1016/j.eswa.2009.02.047

Chen, S. Y. (2009). Identifying and prioritizing critical intellectual capital for e-learning companies. European Business Review, 21(5), 438-452. doi:10.1108/09555340910986664

Garg, R., \& Jain, D. (2017). Fuzzy multi-attribute decision making evaluation of e-learning websites using FAHP, COPRAS, VIKOR, WDBA. Decision Science Letters, 6(4), 351-364. doi:10.5267/j.dsl.2017.2.003

Güldeş, M., Atici, U., \& Şahin, C. (2021). Fuzzy ResourceConstrained Project Scheduling Under Learning Considerations. Paper presented at the International Conference on Intelligent and Fuzzy Systems.

Gürcan, Ö. F., Yazıcı, İ., Beyca, Ö. F., Arslan, Ç. Y., \& Eldemir, F. (2016). Third party logistics (3PL) provider selection with AHP application. Procedia-Social and Behavioral Sciences, $235,226-234$.

Hong, F. L. (2010). Determining the sustainability of virtual learning communities in E-learning platform.
Ishizaka, A., \& Nemery, P. (2013). Multi-criteria decision analysis: methods and software: John Wiley \& Sons.

Işık, A. H., Ince, M., \& Yigit, T. (2015). A fuzzy AHP approach to select learning management system. International Journal of Computer Theory and Engineering, 7(6), 499.

Jami Pour, M., Hosseinzadeh, M., Bagherzadeh Azar, M., \& Taheri, F. (2017). Developing a new framework for evaluating e-learning systems: integrating BSC and FAHP. Kybernetes, 46(8), 1303-1324. doi:10.1108/K-02-2017-0060

Jie, C. (2010). Evaluation and modeling of online course using fuzzy AHP.

Kurilovas, E., \& Vinogradova, I. (2016). Improved fuzzy AHP methodology for evaluating quality of distance learning courses. International journal of engineering education, 32(4), 1618-1624.

Li, L., \& Li, D. (2020) A research of FAHP approach in evaluating online training system alternatives. Vol. 1002 (pp. 40-48): Springer Verlag.

Li, W., Gao, X., \& Fu, G. (2012). Fuzzy comprehensive assessment of network environment and learning quality combined with the Analytic Hierarchy Process.

Lin, C. T., Chang, S. J., \& Chen, Y. H. (2021). Cognitive learning assessment based on FAHP and RSM: A case study of introduction to network course. Journal of Educational Computing Research, 07356331211012685.

Lin, H. F. (2010). An application of fuzzy AHP for evaluating course website quality. Computers and Education, 54(4), 877-888. doi:10.1016/j.compedu.2009.09.017

Linkov, I., \& Moberg, E. (2011). Multi-criteria decision analysis: environmental applications and case studies: CRC Press.

Liu, Q., Peng, R., Chen, A., \& Xie, J. (2009). E-learning platform evaluation using fuzzy AHP.

Lo, T. S., Chang, T. H., Shieh, L. F., \& Chung, Y. C. (2011). Key factors for efficiently implementing customized e-learning system in the service industry. Journal of Systems Science and Systems Engineering, 20(3), 346-364. doi:10.1007/s11518011-5173-y

Mazaheri Asad, M., Ebrahimi Kermani, S., \& Monteiro da Hora, H. R. (2015). A Proposed Framework for Evaluating Student's Performance and Selecting the Top Students in ELearning System, Using Fuzzy AHP Method.

Mehregan, M. R., Jamporazmey, M., Hosseinzadeh, M., \& Mehrafrouz, M. (2011a). Application of fuzzy analytic hierarchy process in ranking modern educational systems' success criteria. International Journal of e-Education, eBusiness, e-Management and e-Learning, 1(4), 299.

Mehregan, M. R., Jamporazmey, M., Hosseinzadeh, M., \& Mehrafrouz, M. (2011b). Proposing an approach for evaluating e-learning by integrating critical success factor and fuzzy AHP. Paper presented at the International conference on innovation, management and service, Singapore.

Nagpal, R., Mehrotra, D., Bhatia, P. K., \& Bhatia, A. (2015). FAHP approach to rank educational websites on usability. International Journal of Computing and Digital Systems, 4(04).

Naveed, Q. N., Qureshi, M. R. N., Alsayed, A. O., Muhammad, A., Sanober, S., \& Shah, A. (2018). Prioritizing barriers of ELearning for effective teaching-learning using fuzzy analytic hierarchy process (FAHP).

Naveed, Q. N., Qureshi, M. R. N., Tairan, N., Mohammad, A., Shaikh, A., Alsayed, A. O., Shah, A., Alotaibi, F. M. (2020). Evaluating critical success factors in implementing e-learning 
system using multi-criteria decision-making. PLoS ONE, 15(5). doi:10.1371/journal.pone.0231465

Saaty, T. L. (1977). A scaling method for priorities in hierarchical structures. Journal of mathematical psychology, 15(3), 234281.

Saaty, T. L. (1980). The analytic hierarchy process (AHP). The Journal of the Operational Research Society, 41(11), 10731076.

Tseng, F. S. C., Chang, I. P., \& Chou, A. Y. H. (2010). Design of an adaptive curriculum portfolio recommendation system by learning object similarity evaluation and Group Decision modeling.

Turker Altun, Y., Baynal, K., \& Turker, T. (2019). The evaluation of learning management systems by using Fuzzy AHP, fuzzy topsis and an integrated method: A case study. Turkish Online Journal of Distance Education, 20(2), 195-218.

Upadhyay, H., Juneja, S., Juneja, A., Dhiman, G., \& Kautish, S. (2021). Evaluation of ergonomics-related disorders in online education using fuzzy AHP. Computational Intelligence and Neuroscience, 2021. doi:10.1155/2021/2214971

Wan, L., Shi, F., \& Zhao, C. (2012). Evaluation of learning content management systems by using fuzzy analytic hierarchy process. Advanced Science Letters, 7, 714-718. doi:10.1166/asl.2012.2736

Wang, C. S., \& Lin, S. L. (2012). Combining fuzzy AHP and association rule to evaluate the activity processes of elearning system. Paper presented at the 2012 Sixth
International Conference on Genetic and Evolutionary Computing.

Wang, C. S., \& Lin, S. L. (2019). How Instructors Evaluate an eLearning System? An Evaluation Model Combining Fuzzy AHP with Association Rule Mining. Journal of Internet Technology, 20(6), 1947-1959.

Xing, H. H. (2010) Study of evaluating web-based courses based on FAHP. Vol. 78. Advances in Intelligent and Soft Computing (pp. 435-443).

Yadegaridehkordi, E., Nizam Bin Md Nasir, M. H., Fazmidar Binti Mohd Noor, N., Shuib, L., \& Badie, N. (2018). Predicting the adoption of cloud-based technology using fuzzy analytic hierarchy process and structural equation modelling approaches. Applied Soft Computing, 66, 77-89. doi:https://doi.org/10.1016/j.asoc.2017.12.051

Yang, M., \& Chen, Y. (2010). The research of evaluation system of network self-learning based on fuzzy theory.

Yazici, I., Beyca, O. F., Gurcan, O. F., Zaim, H., Delen, D., \& Zaim, S. (2020). A comparative analysis of machine learning techniques and fuzzy analytic hierarchy process to determine the tacit knowledge criteria. Annals of Operations Research, $1-24$

Zare, M., Pahl, C., Rahnama, H., Nilashi, M., Mardani, A., Ibrahim, O., \& Ahmadi, H. (2016). Multi-criteria decision making approach in E-learning: A systematic review and classification. Applied Soft Computing Journal, 45, 108-128. doi:10.1016/j.asoc.2016.04.020 